\title{
Research Article \\ Caring for Students: What Teachers Have to Say
}

\author{
Rubén Garza, ${ }^{1}$ Elba Armandina Alejandro, ${ }^{2}$ Tucker Blythe, ${ }^{3}$ and Kathy Fite ${ }^{1}$ \\ ${ }^{1}$ Department of C\&I, Texas State University, 601 University Drive, San Marcos, TX 78666, USA \\ ${ }^{2}$ Bastrop ISD, Bastrop, TX 78602, USA \\ ${ }^{3}$ Texas Education Agency, Austin, TX 78701, USA \\ Correspondence should be addressed to Rubén Garza; ruben.garza2001@gmail.com
}

Received 27 November 2013; Accepted 16 January 2014; Published 3 March 2014

Academic Editors: M. J. Cabral dos Santos Reis, V. Kann, and W.-C. Shih

Copyright (C 2014 Rubén Garza et al. This is an open access article distributed under the Creative Commons Attribution License, which permits unrestricted use, distribution, and reproduction in any medium, provided the original work is properly cited.

In this exploratory qualitative study we examined teachers' perceptions of teacher behaviors that convey caring in upper elementary and middle school classrooms. Data collection included teacher interview, classroom observations, and teacher self-reflection. Major findings include specific caring behaviors perceived by teachers that are identified and described in four themes: (a) fostering a sense of belonging, (b) getting to know students personally, (c) supporting academic success, and (d) attending to physiological needs. Our findings contribute to a body of research on caring by including teachers' voices and illuminating an authentic approach in caring for students. Our description of caring behaviors and patterns of interactions demonstrate caring in ways that may not be congruent with the norm. Thus, our findings may provide new insight for educators to examine their personal ideology.

\section{Introduction}

While the ethnic and linguistic texture of today's classrooms has changed, children face insecurities and stress which can make adjustment in a diverse classroom difficult; therefore, teachers must create a safe and caring environment for all students. "A positive or negative response could affect the self-esteem and academic success of students" [1, page 1]. Sanacore [2] points out that all students, regardless of race, benefit from the genuine caring efforts of teachers. Although students can recognize environments that do not cultivate caring relationships [3], sometimes it is difficult to identify the behaviors that evoke a feeling of care in a student. Therefore, what makes caring a challenging notion is teachers' understanding of how they should care for their students which may not be congruent with their students' expectations $[4,5]$. In addition, teacher experiences and how they perceive the world may sometimes obstruct caring for students whose backgrounds are ethnically, linguistically, and culturally unique making this challenge more complex. The challenge for teachers is to demonstrate caring behaviors responsive to students' needs. Noddings [6] advances this notion by adding that "caring teachers listen and respond differentially to their students" (page 19). In other words, caring is demonstrated in ways congruent with the individual's needs. For example, the following teacher statements convey different conceptions of caring: "I go to their homes if they get into trouble"; "I pay attention to who their friends are outside of class"; "I pay for their breakfast"; "I integrate caring behavior into lessons"; and "I write them I care notes." These perceptions of caring are influenced by the context of the classroom, the community, and their own background and life experiences. While these statements reflect teachers' varied perceptions about caring, they also convey a way of interacting that may not be responsive to students' needs. Educators cannot disregard the significance of the affective domain in developing successful academic students. As Noddings [6] acknowledges "When we understand that everyone wants to be cared for and that there is no recipe for caring, we see how important engrossment (or attention) is" (page 17).

The purpose of our study was to examine teacher behaviors that demonstrated acts of caring in upper elementary and middle school classrooms. This paper addresses how studying teacher behaviors that demonstrate caring can inform what we currently know about practices that are helpful to students. In addition, our paper provides insight that may be helpful in examining current schooling ideologies in any geographical, national, or international context and 
illuminates the behaviors and patterns of interactions that demonstrate effective caring practices.

\section{Literature Review}

Caring has been described as providing the necessary scaffolds $[7,8]$, helping and expecting all students to reach their potential [9], or empathic listening [10-13]. Pang [14] views caring as a conscious and ethical responsibility that supports relationship building with students. While the era of accountability seems to have fostered mechanistic educational organizations that focus on numbers, statistics, and state rankings, educators may view caring as preparing students to do well on state mandated assessments.

Whereas Noddings [6] views caring as a reciprocal act, Mayeroff [15] explains that caring does not have to be reciprocal, but both concur that the ethic of caring involves a relationship between someone who cares for another. Mayeroff [15] considers "knowing, alternating rhythms, patience, honesty, trust, humility, hope, and courage" as key aspects of a caring context (pages 9-20). To care for people requires an interest and action for their welfare, influenced by context and perspective $[16,17]$. On the other hand, Noddings [18] suggests that "we might describe caring of different sorts, on different levels and at varying degrees of intensity" (page 17). Therefore, to care for others is also demonstrated through my actions. As Blustein [16] reiterates, "in general, I take an interest in the things and people I care about when I make their condition my active concern because I identify myself with them in some way" (page 31).

According to Mayeroff [15], caring is about the journey that is advanced for the travelers through mutual interaction. This process involves knowing the individual and understanding his needs rather than generalizing what he may need. This means that teachers must consciously know their students and care for them in a culturally responsive way because students' perceptions about their teachers as caring or noncaring influence how they interact at school [19]. Cultivating caring relationships with students foster engagement in school [20] and promote learning [21].

A significant body of work supports the importance of a caring teacher in the classroom [6, 22-25]. While student success and a teacher's ability to demonstrate genuine caring are linked, Collinson et al. [25] acknowledge that only "...cursory attention (is given) to the role of an ethic of care in effective teaching" (page 22). While "helping a child struggling with a task, verbally expressing kindness and encouraging children with words and actions" [26, page 1189 ] are few actual classroom practices identified by research, caring teachers purposefully know their students well and establish relationships with them because students value the personal interaction $[1,14,27-31]$.

\section{Methodology}

This qualitative study used a grounded theory approach and constant comparative analysis $[32,33]$ to examine and to which can identify specific teacher behaviors that demonstrate caring. Our study, anchored within the ethos of care $[6,18]$ used an interpretive methodological approach to describe the theoretical explanations suggested by the data [34]. The following questions guided this investigation: how do teachers demonstrate caring for their students? What is the nature of those behaviors?

3.1. Participants. Purposive sampling was used in the selection of educators, teaching in suburban schools in the southern part of the United States [35]. The study was conducted during the fall months of an academic school year (August-December). We were specifically interested in working with teachers who had previously taught upper elementary grades, 5th or 6th grade, or middle school, and represented different ethnic backgrounds and ages. Although ethnicity and age were not central to our focus of study, these factors contributed to the diversity of the participants.

The campus administrators provided the names of individuals they perceived as caring teachers and briefly explained their choices. The researchers selected four participants who were perceived as being compassionate and had a reputation for establishing nurturing and caring relationships with all students by campus administrators. These teachers matched the other established sampling characteristics regarding ethnicity, and upper elementary or middle school teaching experience. The four teachers signed a consent form and agreed to participate in this research study.

The number of teachers in our study was limited to four and determined by teacher availability and manageability for observation. Specific and varied examples describing how these teachers cared for and about their students were conveyed based on observations of the participants' interactions with students in formal and informal situations.

The participants included an African-American, Hispanic, Korean, and White female educators (female teachers are more prevalent in the grades represented in our study and were more readily accessible). Their ages ranged from early 30 s to over 65 years old. The African-American and Korean educators both taught at the upper elementary level in an urban school setting. The White and Hispanic teachers taught at the same suburban middle schools. The White middle school teacher was in her forties and had taught about twenty years. This educator specialized in mathematics and was also a girls' sports coach. The other teacher, a Hispanic in her thirties, had taught about eight years and taught Spanish as a second language.

The African-American elementary school teacher was not a full-time educator at the time of this study. She was a retiree in her sixties who had been rehired as a permanent substitute teacher for a particular elementary school. Her career spanned thirty years and had taught all grade levels as well as serving as an assistant principal during the latter part of her career. The second elementary school teacher was in her early thirties, of Korean descent, and had about five-year teaching experience. This teacher had previously taught at the middle school level and was currently assigned to teach in a first grade classroom. The African-American 
and Korean-American educators both taught at the same urban elementary school site. Their rich experiences and solid reputations provided a context that contributed to our study.

3.2. Data Sources. Data sources used in this study included a (1) teacher interview, (2) classroom observations, and (3) teacher reflection. The first instrument consisted of a teacher interview that lasted approximately one hour. Interview questions created by the team were used to provide internal consistency among the four interviews and to collect participants' perceptions about caring for students. The following question initiated each interview: what is your understanding of the following terms: caring actions and demonstrations of caring? Interviewers then probed for more information by asking if the teachers could think of any other specific terms or actions that communicated caring to students. The interviewers, the second and third authors, were flexible in asking the questions in any order and took license to change the wording of any question, as appropriate, while probing for claritfy or to gain additional information [35]. Each interview was tape recorded and then transcribed for data analysis.

The second instrument consisted of classroom observations. The purpose of these observations was to document teacher behavior and interaction with students to identify concrete acts of caring. The second author observed the two middle school classrooms and another observed the two elementary settings. All teachers were observed once for about one hour. In addition, notes were taken during the transition period between classes in order to record how the teachers interacted with students who were not currently coming or going to their specific classrooms.

The final instrument consisted of a reflective narrative. Each teacher was asked to submit a reflective, thoughtful written document describing one incident that defined or characterized her personal perspective of a caring ethos. Each teacher's choice for reflection as well as her thoughtful introspection could serve to validate and personalize the other data sources if correlations emerged. These documents are no longer accessible to the researchers.

3.3. Coding. Two of the authors independently began the data analysis process using information gleaned from interviews, field notes collected from classroom observation, and teacher reflections to organize content and identify behaviors relevant to the research focus. The interview transcripts were examined first and preliminary categories were created with descriptive statements. The descriptive statements included specific teacher behavior and language gleaned from the interview transcripts. This procedure was then independently repeated with the field notes and teacher reflections. Constant comparative analysis $[32,33]$ was used to sort the three data sources to further reduce the categories and identify themes with descriptive statements that were exact or paraphrased comments gleaned from the participants' interviews, classroom observations, and self-reflections. The initial coding was then compared and refined to ensure intercoder reliability. Six themes were identified from the data and submitted to the research team for feedback. The six themes, their labels, and their descriptive statements were reviewed before agreeing on the final four themes.

\section{Limitations}

This study is limited by the sampling of participants. Since observations in qualitative research allow the researcher to interpret the behavior that is documented, it is possible for some aspects to remain unnoticed. The gathering of data through interviews requires the listener to process the information without bias. In addition, bias may occur in the gathering, selection, interpretation, and conclusions of data included in this study or in the interpretation of the context in which the phenomena occurred. There also exists the possibility that other researchers might draw different inferences based on the findings of this research investigation.

Finally, since there are not as many transition periods at the elementary level as there are in the middle schools, the elementary teachers were observed more days than the middle school teachers. This might have provided an opportunity to observe more and varied interactions with the elementary teachers.

\section{Major Findings and Discussion}

The purpose of our study was to examine teacher behaviors that demonstrate caring in upper elementary and middle school classrooms and to describe the nature of those behaviors. The following questions guided this investigation: how do teachers demonstrate caring for their students? What is the nature of those behaviors?

The major findings revealed that participants in this study viewed caring as (a) fostering a sense of belonging, (b) getting to know students personally, (c) supporting academic success, (d) and attending to physiological needs.

5.1. Fostering a Sense of Belonging. Fostering a sense of belonging refers to teacher behaviors that convey a sense of family unity, respect, acknowledgment, being valued as a member of the classroom, and emotionally supported in the school environment. While this meaning is similar to Goodenow's [36], the familial aspect and acknowledging students for their accomplishments further advance her definition. Teachers in this study fostered a sense of belonging by promoting the classroom as a family, providing positive nonverbal communication, refraining from nonthreatening verbal communication, conveying a positive disposition toward students, and using proximity to support students. The literature supports that providing emotional support to students has been linked to more student engagement and less behavioral distractions in the classroom $[25,37]$.

Nonverbal communications such as making eye contact with students [38] and smiling are perceived as caring actions. Brooks [23] contends that the most effective teaching occurs in a caring positive atmosphere. These findings are supported in this research study. For example, one participant commented 


\begin{abstract}
Oh my kids love to come to my class. They are so excited to have me for two years in a row. I just love it because I know that they enjoy coming to school and they are happy to be in my class even if they don't like math. They are happy to be here. And so that's, I mean, that's what it's all about. You'll find a way to get them (students) to learn if they're happy. If they don't want to be here, then that's not going to happen.
\end{abstract}

The participants viewed respect [25] and using nonthreatening verbal communication as a way to care for students [19]. One teacher expressed, "I try to be calm and patient," while another teacher stated, "I never raise my voice." These comments reflect the teacher's disposition toward her students and model how a caring teacher can respond to students in an affirming rather than demeaning way. Caring teachers anticipate good behavior. As one teacher stated, "Students really know when you really care about them or when you disrespect them." Employing a noncoercive approach is more likely to positively influence student behavior [39]. Listening to students was another way to demonstrate care for them. One of the teachers mentioned "I generally kneel by the students' desk and I pay attention." This behavior reflects the bond between teacher and student rather than a display of power by an authority figure, in concert with other researches $[12,38]$.

The educators in this study believed that caring for students includes talking directly to students as a group, but more importantly, making an individual contact. The conversations between teacher and students were personal in nature rather than about grades, missed assignments, or homework. Statements such as, "Hey, you okay?" "How was your weekend?" and "Is everything going all right with you?" reflect the teacher's sincere interest in her students. These positive interpersonal behaviors where teachers spend time talking to students about their personal or social issues promote a sense of belonging and strengthen a bond between teacher and student $[4,30,40]$.

5.2. Getting to Know Students Personally. Getting to know students personally refers to knowing about students' academic, socioeconomic, and social backgrounds [14]. Knowing about student's strengths and limitations is necessary to adequately facilitate learning [15]. During the interviews, the four teachers expressed that caring was critical for a successful teacherstudent relationship. Caring about students extended beyond classroom observation [17]; outside information was gathered to assess student learning needs. "I find out if there are issues affecting students' learning and I am sensitive to family emergencies when students get behind or fail to complete assignments," stated one teacher. The teachers believed that showing concern for the students' cognitive needs was one way to care for students [29].

Another teacher stated, "I know if my students have lost parents or siblings or if they have just moved here and have no friends." Being familiar with student living arrangements, contacting parents for information about the student, and being sensitive to family crises such as a death in the family or other types of urgent situations help the teacher to know a student better. As one teacher exclaimed, "I find out if they have a place to live" and another stated "I e-mail parents to find out if there are problems I need to know about." "Caring teachers purposefully know their students well and establish relationships with them" [25, page 1].

Research supports the premise of a genuine bond between an educator and his students. "Students thrive where caring relationships are meaningful, purposeful, and personal" [41, page 357]. "I go to their games," "I go to birthday parties," "I go to their plays," and "I go to their homes to talk to parents" are examples of how the teachers in this study perceived their actions to reflect caring for their students. Caring for students involved visiting their home for family celebrations, attending theatrical and sporting events, and obtaining personal information through student surveys and informal conversations. This type of personal attention is perceived by students as important [7] and helps to foster relationship building between student and teacher [42].

Talking to students about their interests and listening to students are ways to convey a caring ethic $[29,43]$. In contrast, students who perceive an uncaring teacher are more likely to be academically distant [44]. Teacher-student relationships are at the heart of learning. "Strong nurturing relationships support youth, engage them in learning, and focus them on positive thinking and behaviors" [21, page 74]. If students like the teacher, they are more apt to cooperate behaviorally and academically.

\subsection{Supporting Academic Success. Supporting academic suc-} cess refers to teacher behaviors that promote their academic success. Teacher behaviors perceived as caring attributes in this theme include verbally communicating high expectations with students, expressing positive statements to encourage student effort, monitoring and assisting students during learning activities, and individualizing learning outcomes. During a classroom observation, one teacher expressed to a child "Wow, you don't need my help" and "Good thinking" to another. Other statements expressed by another teacher include "Keep going, you can do it" and "You are on the right track." Teachers believed that expressing positive comments to students while they worked on learning tasks demonstrated a caring ethos. These kinds of statements help to promote student self-efficacy [45]. If students perceive they can complete a task successfully, they are more likely to continue on task. During the interview, all four teachers expressed that demonstrating caring actions spurred students to greater personal and academic accomplishments.

The four teachers shared their conceptions about the importance of supporting their students as examples of caring for them. "I walk around the room answering questions and keeping students on task," said one educator. During the classroom observations, the teachers were observed circulating the classroom asking students if they needed further help, answering questions, and providing verbal and nonverbal feedback. As one teacher stated, "I question to guide comprehension." Students favor teachers who assist them in the classroom, help them understand content, and 
will explain concepts more than once if necessary. These perceptions were similar to middle school students' perceptions [13] of a caring teacher. It is interesting that both teachers and students perceived a focus on student comprehension and academic scaffolding during a teaching episode as forms of caring. Sanacore [2] recognizes the importance of a nurturing environment in the establishment of optimal learning opportunities.

Research suggests that students' perceptions of the social environment influence student behavior, cognitive engagement, and their success in school $[37,46]$. "I am sensitive to their extracurricular activities and make assignments accordingly," expressed one teacher. This is an example of individualizing learning outcomes to attend to individual needs rather than an institutional process. One teacher expressed that some students are allowed to complete fewer assignments whenever they demonstrate an understanding of the "big picture." This is an example of differentiating instruction for students to meet their individual academic needs. Rather than requiring a student to meet an assignment quota, the teacher makes an instructional adjustment based on what is academically sound for the child. This behavior enhances the culture for learning by demonstrating to the students that they are cared about [16] and their academic success is a priority.

5.4. Attending to Physiological and Safety Needs. Attending to physiological and safety needs refers to behaviors that tend to bodily and safety needs [47]. Maslow defined the caring and nurturing teacher as one who was compassionate and concerned about her students. The teachers in this study viewed providing nourishment and personal resources to students as caring acts. One teacher shared how she demonstrated care for one of her economically disadvantaged students.

There was a student at this school last year that I noticed was not eating breakfast and his parents were caught in the middle of this. I think it was partial pay and sometimes he would be caught up and sometimes he wouldn't. So I would ask him about eating breakfast and he would say that he didn't have money today and a lot of days he would get peanut butter and jelly. I went to the cafeteria and told them, and then told him, whenever he needs to eat let him eat. I always leave money in there (the cafeteria) and those are things that show that you really care about the kids.

Responding to students' needs by supplying the necessary resources demonstrates a way to help them feel wanted and nurtured in a safe climate. This aspect is in concert with the work of Slaughter-Defoe and Carlson [48]. In a study of third grade students, Latino children perceived school climate as important while African-American children placed greater importance to the affective domain of the school climate. One teacher expressed, "I pay for the students' bus fare." Educators are not obligated to provide monetary or material resources for students but one teacher believed it was the right thing to do. She said the following:
Caring actions to me mean that you care for the kids beyond what your expectations are as teacher and demonstrating of caring means that you do things beyond what is expected of you. For instance, today I gave a student my jacket because she had messed her clothes up. You do for the kids to let them know you really care about them.

Schools need to become caring communities because "for too many young people, the home is no longer a place of security and love but a battleground where economic and emotional survival is a daily reality" [49, page 520]. This last theme reflects the teachers' moral and ethical commitment to care for their students in ways congruent with their own espoused belief about caring [50].

\section{Conclusion}

Our study focuses exclusively on elementary and middle school women who were identified as caring teachers, thus positioning their legitimacy as credible sources to identify ways to demonstrate care for students. The findings of our study contribute to a growing body of work on caring behaviors in several ways. First, the participants' behavior and comments illustrate an authentic approach in caring for students to promote active engagement in the classroom [51]. By interviewing, observing, and reflecting on their actions, the teachers in this study identified key aspects of caring that vividly describe what caring may look like to educators in the classroom.

These findings are especially helpful for teachers who are ethnically unique to their students and whose background and experiences may obstruct caring in ways appropriate for their students. For example, educators in other parts of the world could use these descriptions to reflect on their own practice. In addition, providing preservice teachers with concrete examples of what caring looks like to some teachers can only enhance their pedagogical knowledge and skills and understanding about students' needs in diverse settings and contexts.

Second, our findings support Noddings' [18] idea that caring varies in the way and time invested in caring for others. The teachers in our study suggested authentic ways to effectively demonstrate care for students that may differ from the norm as suggested by other researches [50]. Educators can benefit from these findings by comparing them to their own practices and identifying areas that may need improvement. For example, American teachers may have a similar yet unique perspective about how to demonstrate care for students than teachers in other parts of the world.

Finally, our findings support the premise that the four participants were perceived by the administration and genuinely perceived themselves to exhibit caring behaviors for their students. The findings also clearly illustrate that these four teachers had a desire to know the children in their classes not only as students, but as dynamic people. All four participants engaged students in dialogue reflecting the teacher's interest in the student's academic and social life. Within the classroom, students were additionally made to feel 
welcomed and encouraged to participate. The participants shared that they did only what came naturally to them. If we are willing to accept that caring is an innate quality for some, can we teach others how to care given a set of prescriptive elements? Educators can ill afford to underestimate the powerful presence of a caring and nurturing teacher in today's classrooms. If there is truly a "no child left behind" mandate, then the poster child for this slogan is a caring teacher.

Given that our study was exploratory in nature, further research of a larger sampling of diverse teachers might enhance and extend a discussion of our themes. Our study illuminates teachers' voices and describes effective practices that demonstrated care for students. Further inquiry might include the following questions: what differences exist between elementary, middle school, and high school teachers? Do teacher ethnicity and gender influence teacher perception? Does teacher experience influence perception of behaviors that convey caring? How does a teacher and his/her students agree and disagree over what constitute caring behaviors?

\section{Conflict of Interests}

The authors declare that there is no conflict of interests regarding the publication of this paper.

\section{References}

[1] M. R. Brown, "Educating all students: creating culturally responsive teachers, classrooms, and schools," Intervention in School and Clinic, vol. 43, no. 1, pp. 57-62, 2007.

[2] J. Sanacore, "Genuine caring and literacy learning for African American children," Opinion Paper ED471395, C.W. Post Campus Long Island University, Brookville, NY, USA, Retrieved from ERIC database, 2002.

[3] J. A. Baker, R. Bridger, T. Terry, and A. Winsor, "Schools as caring communities: a relational approach to school reform," School Psychology Review, vol. 26, no. 4, pp. 586-602, 1997.

[4] P. den Brok, M. Brekelmans, and T. Wubbels, "Interpersonal teacher behaviour and student outcomes," School Effectiveness and School Improvement, vol. 15, no. 3-4, pp. 407-442, 2004.

[5] R. Garza, M. N. Ovando, and C. E. Seymour, "Latino and white students' perceptions of teacher behaviors that convey caring: do gender and ethnicity matter?" Current Issues in Education, vol. 13, no. 1, pp. 1-30, 2010.

[6] N. Noddings, The Challenge of Care in Schools, Teachers College Press, New York, NY, USA, 2005.

[7] R. Garza, "She teaches you like if she were your friend: latino high school students describe attributes of a caring teacher," Journal of Border Educational Research, vol. 6, no. 1, pp. 81-90, 2007.

[8] S. Nieto, Affirming Diversity, Pearson, Allyn and Bacon, New York, NY, USA, 4th edition, 2004.

[9] G. Gay, Culturally Responsive Teaching, Teachers College Press, New York, NY, USA, 2000.

[10] N. Alder, "Interpretations of the meaning of care: creating caring relationships in urban middle school classrooms," Urban Education, vol. 37, no. 2, pp. 241-266, 2002.
[11] C. B. Hayes, A. Ryan, and E. B. Zseller, "The middle school child's perceptions of caring teachers," American Journal of Education, vol. 103, no. 1, pp. 1-19, 1994.

[12] M. Hyson and J. L. Taylor, "Caring about caring: what adults can do to promote young children's prosocial skills," National Association for the Education of Young Children, 2011, http://www.naeyc.org/files/yc/file/201107/CaringAboutCaring _Hyson_OnlineJuly2011.pdf.

[13] K. R. Wentzel, "Student motivation in middle school: the role of perceived pedagogical caring," Journal of Educational Psychology, vol. 89, no. 3, pp. 411-419, 1997.

[14] V. O. Pang, Multicultural Education: A Caring-Centered Reflective Approach, McGraw Hill, New York, NY, USA, 2005.

[15] M. Mayeroff, On Caring, Harper and Row, New York, NY, USA, 1971.

[16] J. Blustein, Caring and Commitment: Taking the Personal Point of View, Oxford University Press, New York, NY, USA, 1991.

[17] S. Acker, "The work of women teachers," British Journal of Sociology of Education, vol. 16, no. 1, pp. 21-36, 1995.

[18] N. Noddings, Caring, University of California Press, Berkeley, Calif, USA, 1984.

[19] M. M. Ferreira and K. Bosworth, "Defining caring teachers: adolescents'perspectives," Journal of Classroom Interaction, vol. 36, no. 1, pp. 24-30, 2001.

[20] D. Stipek, "Relationships matter," Educational Leadership, vol. 64, no. 1, pp. 46-49, 2006.

[21] P. C. Scales and J. Taccogna, "Caring to try: how building students'developmental assets can promote school engagement and success," NASSP Bulletin, vol. 84, no. 619, pp. 69-78, 2000.

[22] G. Anderson, "Closing the Achievement Gap for all Students," Title One Conference Presentation, Florida Department of Education, 2004.

[23] R. Brooks, "Education and "charismatic" adults: to touch a student's heart and mind," 2000, http://www.drrobertbrooks.com /writings/articles/0009.html.

[24] M. A. Bruce and J. Stellern, "Building a caring community in teacher education," The Teacher Educator, vol. 41, no. 1, pp. 3451, 2005.

[25] V. Collinson, M. Killeavy, and J. Stephenson, "Exemplary teachers: practicing an ethic of care in England, Ireland, and the United States," in Proceedings of the meeting of the American Educational Research Association, San Diego, Calif, USA, 1998.

[26] K. T. Nowak-Fabrykowki, "An analysis of caring behavior among early childhood teachers and children," Early Child Development and Care, vol. 182, no. 9, pp. 1185-1102, 2012.

[27] A. De Jesús and R. Antrop-González, "Instrumental relationships and high expectations: exploring critical care in two Latino community-based schools," Intercultural Education, vol. 17, no. 3, pp. 281-299, 2006.

[28] M. E. Franquiz and M. D. C. Salazar, The Transformative Potential of Humanizing Pedagogy: Addressing the Diverse Needs of Chicano/Mexicano Students, The University of North Carolina Press, 2004.

[29] R. Garza, "Latino and white high school students' perceptions of caring behaviors: are we culturally responsive to our students?" Urban Education, vol. 44, no. 3, pp. 297-321, 2009.

[30] P. Hansen and J. A. Mulholland, "Caring and elementary teaching the concerns of male beginning teachers," Journal of Teacher Education, vol. 56, no. 2, pp. 119-131, 2005. 
[31] M. Pizarro, Chicanas and Chicanos in Schools, The University of Texas Press, 2005.

[32] B. G. Glaser and A. L. Strauss, The Discovery of Grounded Theory: Strategies for Qualitative Research, Aldine, New York, NY, USA, 1967.

[33] A. Strauss and J. Corbin, Basics of Qualitative Research, Sage, Thousand Oaks, Calif, USA, 1998.

[34] M. D. Gall, W. R. Borg, and J. P. Gall, Educational Research: An Introduction, Longman, White Plains, NY, USA, 1996.

[35] B. Johnson and L. Christensen, Educational Research: Quantitative, Qualitative, and Mixed Approaches, Pearson Learning, Boston, Mass, USA, 2nd edition, 2004.

[36] C. Goodenow, "Classroom belonging among early adolescent students," The Journal of Early Adolescence, vol. 13, no. 1, pp. 2143, 1993.

[37] H. Patrick, A. M. Ryan, and A. Kaplan, "Early adolescents' perceptions of the classroom social environment, motivational beliefs, and engagement," Journal of Educational Psychology, vol. 99, no. 1, pp. 83-98, 2007.

[38] C. Bulach, C. Brown, and L. Potter, "Behaviors that create a caring learning community," in A presentation at the Southern Regional Council of Education Administration, Savannah, Ga, USA, 1996.

[39] M. Marshall, "How to create a learning community," 2001, http://www.marvinmarshall.com/responsibility/how-to-create -a-learning-community/.

[40] V. Battistich, D. Solomon, M. Watson, and E. Schaps, "Caring school communities," Educational Psychologist, vol. 32, no. 3, pp. 137-151, 1997.

[41] M. Wilder, "Culture, race, and schooling: toward a con-colorblind ethic of care," The Educational Forum, vol. 63, no. 4, pp. 356-362, 1999.

[42] M. F. Koepke and D. A. Harkins, "Conflict in the classroom: gender differences in the teacher-child relationship," Early Education and Development, vol. 19, no. 6, pp. 843-864, 2008.

[43] L. Morganett, "Good teacher-student relationships: a key element in classroom motivation and management," Education, vol. 112, pp. 260-264, 1991.

[44] K. Osterman and S. Freese, "Nurturing the mind to improve learning: teacher caring and student engagement," in The Academic Achievement of Minority Students: Perspectives, Practices, and Prescriptions, S. T. Gregory, Ed., pp. 287-305, University Press of America, Lanham, Md, USA, 2000.

[45] A. Bandura, "Bandura's social learning theory," in Theories of Development: Concepts and Applications, W. Crain, Ed., pp. 175192, Prentice Hall, Englewood Cliffs, NJ, USA, 3rd edition, 1992.

[46] E. van de Gaer, H. Pustjens, J. van Damme, and A. de Munter, "The gender gap in language achievement: the role of schoolrelated attitudes of class groups," Sex Roles, vol. 55, no. 5-6, pp. 397-408, 2006.

[47] A. Maslow, "A theory of human motivation," in Motivation and Personality, A. Maslow, Ed., pp. 35-46, Harper and Row Publishing, New York, NY, USA, 1970.

[48] D. T. Slaughter-Defoe and K. G. Carlson, "Young African American and Latino children in high-poverty urban schools: how they perceive school climate," Journal of Negro Education, vol. 65 , no. 1, pp. 60-70, 1996.

[49] H. F. Wolfgram, "Needed: an ethic of caring in our schools," Education, vol. 115, no. 4, pp. 516-521, 1995.
[50] T. Barber, "'A special duty of care': exploring the narration and experience of teacher caring," British Journal of Sociology of Education, vol. 23, no. 3, pp. 383-395, 2002.

[51] S. A. Perez, "An ethic of caring in teaching culturally diverse students," Education, vol. 121, no. 1, pp. 102-105, 2000. 